\title{
PHYTOCHEMICAL CONSTITUENTS OF THE LEAVES OF LEUCAENA LEUCOCEPHALA FROM MALAYSIA
}

\author{
MOHAMED ZAKY ZAYED ${ }^{*}$, BENEDICT SAMLING² \\ ${ }^{1}$ Forestry and Wood Technology Department, Faculty of Agriculture (EL-Shatby), Alexandria University, Alexandria, \\ Egypt, ${ }^{2}$ Chromatography Laboratory, Faculty of Resource science and Technology (FRST), University Malaysia Sarawak (UNIMAS), \\ Sarawak, Malaysia \\ Email: zaky_tree@yahoo.com
}

Received: 08 Mar 2016 Revised and Accepted: 15 Oct 2016

\begin{abstract}
Objective: This study was conducted to identify the phytochemical constituents of Leucaena leucocephala leaf extracts using gas chromatographymass spectrometry (GC-MS).

Methods: Hexane, petroleum ether, chloroform, ethyl acetate and methanol leaves extract of L. leucocephala were analyzed using GC-MS, while the mass spectra of the compounds found in the extract were matched with the National Institute of Standards and Technology (NIST) library.

Results: GC-MS analysis of L. leucocephala leaves revealed the presence of 30 compounds and the major chemical constituents were Squalene (41.02\%), Phytol (33.80\%), 3,7,11,15-Tetramethyl-2-hexadecen-1-ol (30.86\%) and 3,7,11-Tridecatrienenitrile, 4,8,12-trimethyl (25.64\%). Some of these compounds have been reported to possess various biological activities such as antioxidant, antimicrobial, hepatoprotective, antiparasitic, insecticide, nematicide, pesticide, anti coronary, antiarthritic, antiandrogenic, hypocholesterolemic, cancer preventive, anti-cancer, analgesic, anesthetic, allergenic and etc.
\end{abstract}

Conclusion: The findings of this study indicating that $L$. leucocephala leaves possess various potent bioactive compounds and is recommended as a plant of phytopharmaceutical importance.

Keywords: Leucaena leucocephala, Medicine, Phytochemical, Chromatography-mass spectrometry (GC-MS), Phytopharmaceutical, antioxidant.

(C) 2016 The Authors. Published by Innovare Academic Sciences Pvt Ltd. This is an open access article under the CC BY license (http://creativecommons.org/licenses/by/4. 0/] DOI: http://dx.doi.org/10.22159/ijpps.2016v8i12.11582

\section{INTRODUCTION}

Leucaena leucocephala trees or Petai belalang as it is locally known in Malaysia [1] is a tropical multipurpose tree species. Central America and Southeast Asia's genus, Leucaena (English name), formerly contained approximately 50 species of both trees and shrubs that belonged to the Mimosoideae's subfamily of the Fabaceae family. $L$. leucocephala was known as miracle tree because of its worldwide success as a long-lived and highly nutritious forage tree, used as firewood, timber, human food, green manure, shade and erosion control and it is estimated to cover 2-5 million ha worldwide [2, 3]. Almost every part of the L. leucocephala species is consumed as human food since the era of the Mayans [4]. In Indonesia, Thailand, and Central America, people eat the young leaves, flowers, and young pods in soups $[5,6]$. In addition, it is one of the medicinal plants used to control stomach ache, like contraception and abortifacient. Bioactivity studies on this plant revealed its anthelmintic, antibacterial, antiproliferative and antidiabetic activities [7].

Various phytochemical compounds have been identified from $L$. leucocephala using phytochemistry approaches to date. The phytochemical screening of leaf extract of $L$. leucocephala revealed the presence of various secondary metabolites as phylobatanins, alkaloid, cardiac glycosides, tannins, flavonoids, saponins and Glycosides [3]. The chemical constituents of the whole plants extracts of $L$. leucocephala from China were ficaprenol-11 (polyprenol), squalene, lupeol,-sitostenone, trans-coumaric acid, ciscoumaric acid, pheophytin-a, pheophorbide a methyl ester, methyl132-hydroxy-(132-S)-pheophorbide-b and aristophyll-C [8], while the principal chemical constituents of the leaves extracts of the same plant from Mexico were 2(H)-benzofuranone-5,6,7,7a-tetrahydro4,4,7a-trimethyl, pentadecanoic acid-14-methyl-methyl ester, and 6,10,14-trimethyl-2-pentadecanone a ketone [9].

To the best of our knowledge, since no information is available on the phytochemical screening of L. leucocephala leaves from Malaysia.
Therefore, the present study was undertaken to investigate the extraction and phytochemical investigations of L. leucocephala leaves from Malaysia.

\section{MATERIALS AND METHODS}

\section{Plant material}

L. leucocephala leaves were collected from Stutong located between $1^{\circ} 31^{\prime} 8 " N$ Latitude and $110^{\circ} 22^{\prime} 41^{\prime \prime E}$ longitude in Kuching, Sarawak, Malaysia. The plant materials were taxonomically identified and confirmed by Dr. Mohamed Zayed, Forestry and Wood Technology Department, Faculty of Agriculture (EL-Shatby), Alexandria University, Alexandria, Egypt. Leaves were washed and dried at $30{ }^{\circ} \mathrm{C}$ in an oven until constant weights and ground to a powder with an electric blender.

\section{Sample extraction}

$25 \mathrm{gm}$ of the leaf powder of L. leucocephala for each solvent were weighted, transferred to a flask, treated with hexane, petroleum ether, chloroform, ethyl acetate and methanol until the powder was fully immersed and incubated overnight. The extracts were then filtered through Whatman filter paper No.1 along with 2 gm sodium sulfate to remove the sediments and traces of water in the filtrate. Before filtering, the filter paper along with sodium sulphate was wetted $95 \%$ ethanol. The filtrates were then air dried and subjected to gas chromatography-mass spectrometry analysis.

\section{Gas chromatograph-mass spectroscopy (GC-MS)}

GC-MS (Shimadzu QP 5000) was performed by using non-polar DB-5 cross-linked column (30 m long x $0.25 \mathrm{~mm}$ ID x $0.25 \mu \mathrm{m}$ film thickness composed of $5 \%$ phenyl methyl polysiloxane). The initial temperature was programmed at $50{ }^{\circ} \mathrm{C}$ and held for two minutes, and then it was increased to $300{ }^{\circ} \mathrm{C}$ with the rate of $6.5^{\circ} \mathrm{C} / \mathrm{min}$. The final temperature was held for ten minutes. The temperature of the injector and detector 
were set up to $280{ }^{\circ} \mathrm{C}$ and $300{ }^{\circ} \mathrm{C}$, respectively. Helium gas was used as a carrier gas. $1 \mu \mathrm{l}$ of the fractions was diluted in $100 \mu \mathrm{l}$ hexane and then injected into the GC-MS [24-25]. Interpretation of mass-spectrum was conducted using the database of National Institute Standard and Technology (NIST). The spectrum of the unknown components was compared with the spectrum of known components stored in the NIST library. The name, molecular mass and structure of the components of the test materials were ascertained.

\section{RESULTS AND DISCUSSION}

This is the first study for the phytochemicals screening of $L$. leucocephala leaves from Malaysia. The components present in the hexane, petroleum ether, chloroform, ethyl acetate and methanol extracts of L. leucocephala leaves were identified by GC-MS analyzed (fig. 1, 2, 3, 4 and 5). 30 phytocomponents from the L. leucocephala leaves have been identified from all the solvent extracts after comparison of the mass spectra with NIST library (table 1) and the major chemical constituents were Squalene (41.02\%), Phytol (33.80\%), 3,7,11,15-Tetramethyl-2-hexadecen-1-ol (30.86\%) and 3,7,11-Tridecatrienenitrile, 4,8,12-trimethyl (25.64\%). In the present investigation, the compounds analyzed in the hexane extracts of L. leucocephala leaves were five important compounds and these include tetratetracontane, oxalic acid, allyl hexadecyl ester, squalene, octacosane and hexatriacontane (fig. 1). Meanwhile, six important compounds identified in the petroleum ether extract of L. leucocephala leaves as 5-octadecene, 1-octadecyne, 3,7,11,15tetramethyl-2-hexadecen-1-ol, pentadecanoic acid, 14-methyl-, methyl ester, 9,12-octadecadienoic acid, methyl ester and squalene (fig. 2). Four compounds were detected in the chloroform extract. The compounds were 3,7,11,15-tetramethyl-2-hexadecen-1-ol, hexadecanoic acid, 15-methyl-, methyl ester, 9,12,15-octadecatrienoic acid, methyl ester and 3,7,11-tridecatrienenitrile, 4,8,12-trimethyl (fig. 3). For ethyl acetate extract, nine active component detected were 2dodecene, 7-hexadecene, 5-octadecene, 1-octadecyne, 3,7,11,15tetramethyl-2-hexadecen-1-ol, 5-eicosene, 9,12,15-octadecatrienoic acid, methyl ester, 1-docosene and squalene (fig. 4). Six photo components were also successfully identified in the methanol extract of L. leucocephala leaves as 3,7,11,15-tetramethyl-2-hexadecen-1-ol, heptacosanoic acid, methyl ester, n-hexadecanoic acid, 9,12,15octadecatrienoic acid, methyl ester, phytol and squalene (fig. 5).

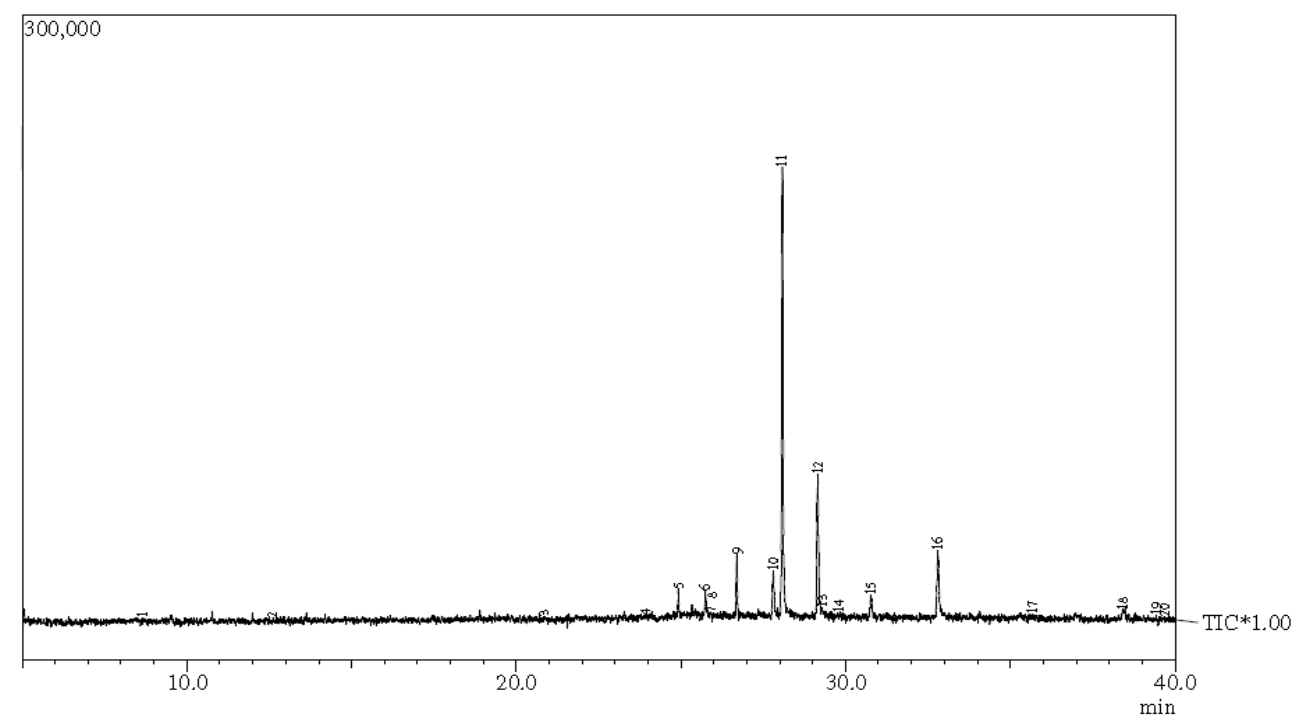

Fig. 1: Gas chromatogram of the hexane extract of the leaves of L. leucocephala. Tetratetracontane (9), (10) 0xalic acid, allyl hexadecyl ester, (11) Squalene, (12) Octacosane, (16) Hexatriacontane

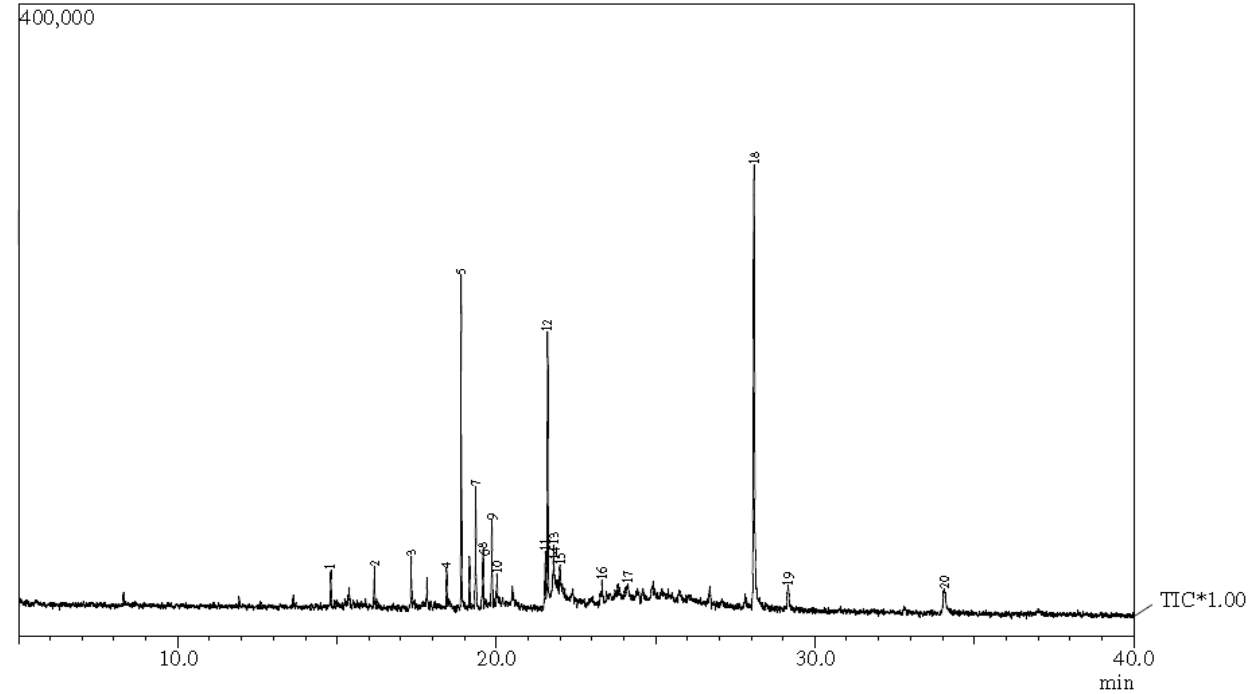

Fig. 2: Gas chromatogram of the petroleum ether extract of the leaves of L. leucocephala. 5-Octadecene (2), (3) 2-Bromotetradecane, (5) 1Octadecyne, (7) 3,7,11,15-Tetramethyl-2-hexadecen-1-ol, (8) Eicosane, (9) Pentadecanoic acid, 14-methyl-, methyl ester, (12) 9,12Octadecadienoic acid, methyl ester, (18) Squalene 


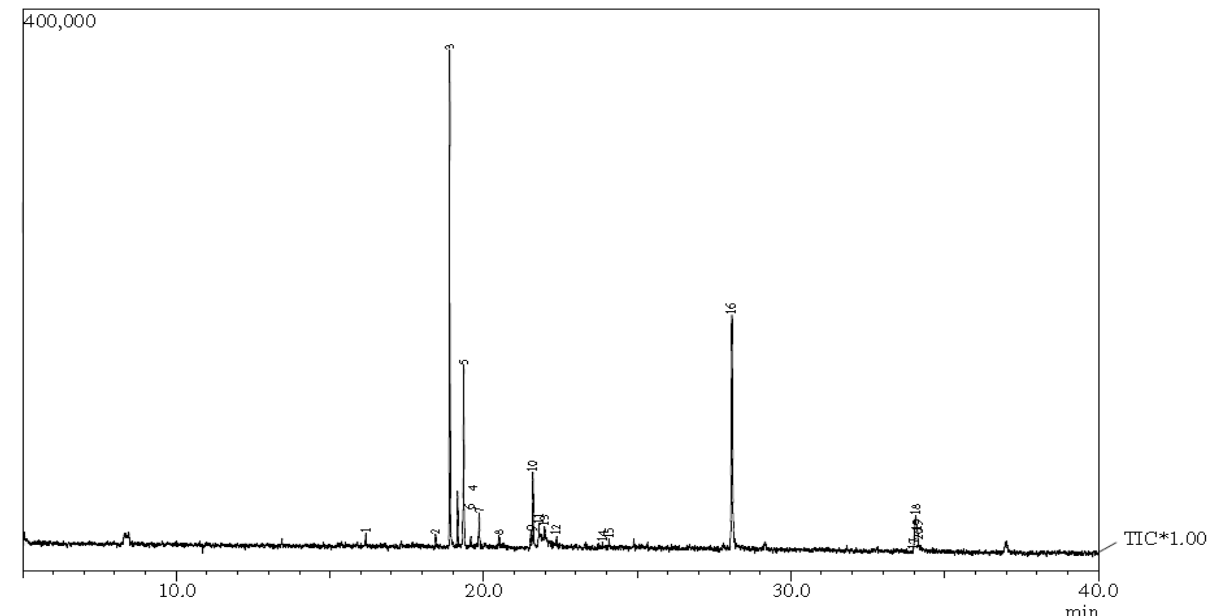

Fig. 3: Gas chromatogram of the Chloroform extract of the leaves of L. leucocephala. 3,7,11,15-Tetramethyl-2-hexadecen-1-ol (5), (7) Hexadecanoic acid, 15-methyl-, methyl ester, (10) 9,12,15-Octadecatrienoic acid, methyl ester, (16) 3,7,11-Tridecatrienenitrile, 4,8,12-trimethyl

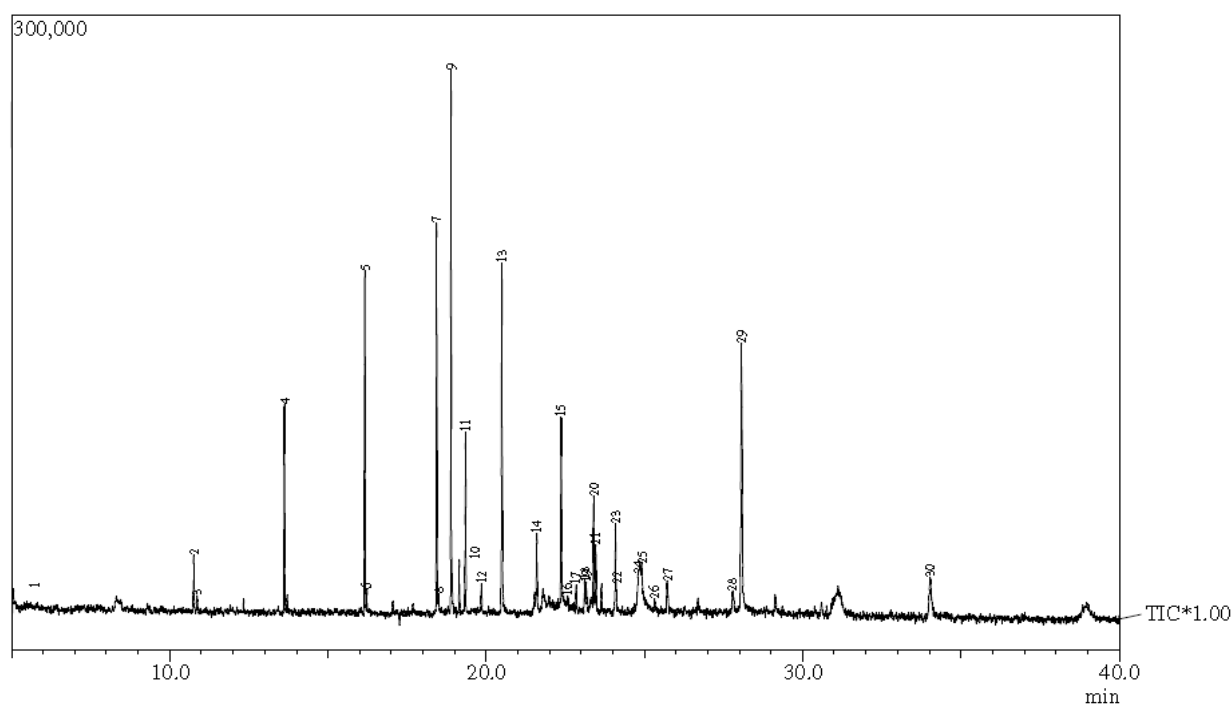

Fig. 4: Gas chromatogram of the ethyl acetate extract of the leaves of L. leucocephala. 2-Dodecene (2), (4) 7-Hexadecene, (7) 5-0ctadecene, (9) 1-Octadecyne, (11) 3,7,11,15-Tetramethyl-2-hexadecen-1-ol, (13) 5-Eicosene, (14) 9,12,15-Octadecatrienoic acid, methyl ester, (23) 1Docosene, (29) Squalene

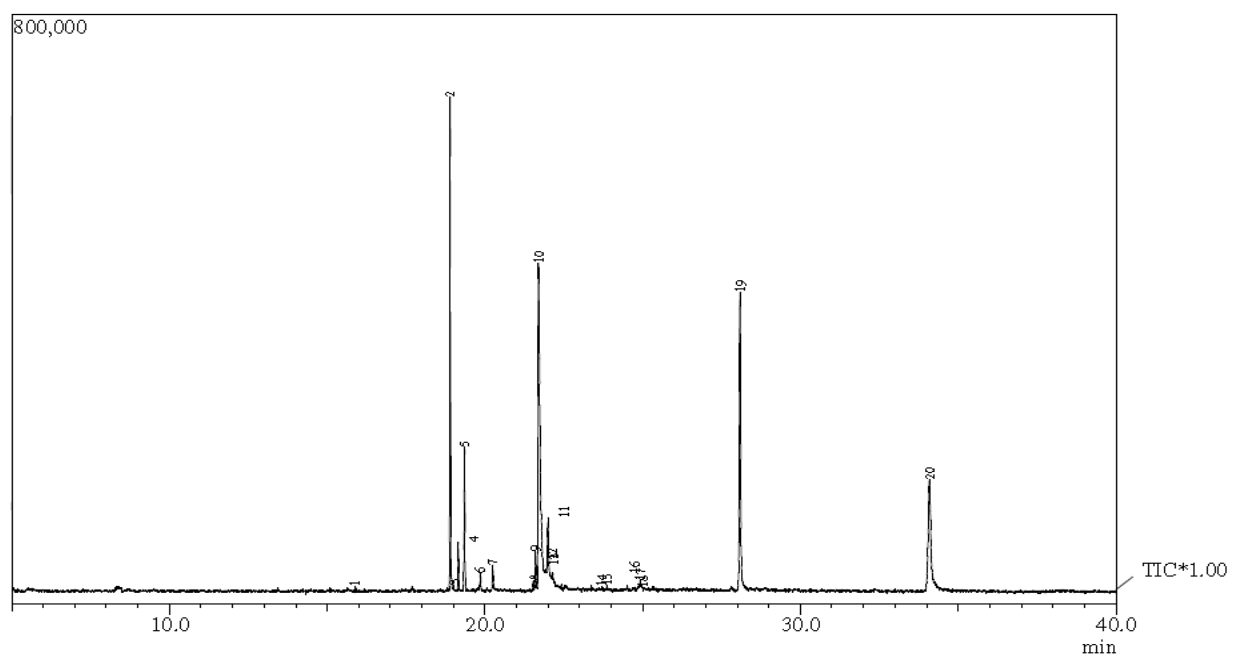

Fig. 5: Gas chromatogram of the methanol extract of the leaves of $L$. leucocephala. 3,7,11,15-Tetramethyl-2-hexadecen-1-ol (2), (6) Heptacosanoic acid, methyl ester, (7) n-Hexadecanoic acid, (9) 9,12,15-Octadecatrienoic acid, methyl ester, (10) Phytol, (19) Squalene 
Table 1: Phytochemicals screening of solvent extracts of $\boldsymbol{L}$. leucocephala leaves by GC-MS

\begin{tabular}{|c|c|c|c|c|c|}
\hline No. & R. Time & Name of the compound & Molecular formula & Molecular weight & Peak area \% \\
\hline \multicolumn{6}{|c|}{ Hexane extract } \\
\hline 1 & 26.69 & Tetratetracontane & $\mathrm{C}_{44} \mathrm{H}_{90}$ & 618 & 5.03 \\
\hline 2 & 27.80 & Oxalic acid, allyl hexadecyl ester & $\mathrm{C}_{21} \mathrm{H}_{38} \mathrm{O}_{4}$ & 354 & 6.05 \\
\hline 3 & 28.08 & Squalene & $\mathrm{C}_{30} \mathrm{H}_{50}$ & 410 & 41.02 \\
\hline 4 & 29.15 & Octacosane & $\mathrm{C}_{28} \mathrm{H}_{58}$ & 394 & 16.00 \\
\hline 5 & 32.80 & Hexatriacontane & $\mathrm{C}_{36} \mathrm{H}_{74}$ & 506 & 9.50 \\
\hline \multicolumn{6}{|c|}{ Petroleum ether extract } \\
\hline 1 & 16.16 & 5-Octadecene & $\mathrm{C}_{18} \mathrm{H}_{36}$ & 252 & 1.83 \\
\hline 2 & 18.90 & 1-Octadecyne & $\mathrm{C}_{18} \mathrm{H}_{34}$ & 250 & 12.10 \\
\hline 3 & 19.35 & 3,7,11,15-Tetramethyl-2-hexadecen-1-ol & $\mathrm{C}_{20} \mathrm{H}_{40} \mathrm{O}$ & 296 & 5.93 \\
\hline 4 & 19.86 & Pentadecanoic acid, 14-methyl-, methyl ester & $\mathrm{C}_{17} \mathrm{H}_{34} \mathrm{O}_{2}$ & 270 & 3.77 \\
\hline 5 & 21.53 & 9,12-Octadecadienoic acid, methyl ester & $\mathrm{C}_{19} \mathrm{H}_{34} \mathrm{O}_{2}$ & 294 & 2.38 \\
\hline 6 & 28.08 & Squalene & $\mathrm{C}_{30} \mathrm{H}_{50}$ & 410 & 30.47 \\
\hline \multicolumn{6}{|c|}{ Chloroform extract } \\
\hline 1 & 18.89 & 3,7,11,15-Tetramethyl-2-hexadecen-1-ol & $\mathrm{C}_{20} \mathrm{H}_{40} \mathrm{O}$ & 296 & 30.86 \\
\hline 2 & 19.85 & Hexadecanoic acid, 15-methyl-, methyl ester & $\mathrm{C}_{18} \mathrm{H}_{36} \mathrm{O}_{2}$ & 284 & 2.08 \\
\hline 3 & 21.60 & $9,12,15$-Octadecatrienoic acid, methyl ester & $\mathrm{C}_{19} \mathrm{H}_{32} \mathrm{O}_{2}$ & 292 & 5.88 \\
\hline 4 & 28.08 & 3,7,11-Tridecatrienenitrile, 4,8,12-trimethyl & $\mathrm{C}_{16} \mathrm{H}_{25} \mathrm{~N}$ & 231 & 25.64 \\
\hline \multicolumn{6}{|c|}{ Ethyl acetate extract } \\
\hline 1 & 10.75 & 2-Dodecene & $\mathrm{C}_{12} \mathrm{H}_{24}$ & 168 & 1.66 \\
\hline 2 & 13.62 & 7-Hexadecene & $\mathrm{C}_{16} \mathrm{H}_{32}$ & 224 & 5.23 \\
\hline 3 & 18.43 & 5-Octadecene & $\mathrm{C}_{18} \mathrm{H}_{36}$ & 252 & 9.59 \\
\hline 4 & 18.89 & 1-Octadecyne & $\mathrm{C}_{18} \mathrm{H}_{34}$ & 250 & 13.67 \\
\hline 5 & 19.35 & 3,7,11,15-Tetramethyl-2-hexadecen-1-ol & $\mathrm{C}_{20} \mathrm{H}_{40} \mathrm{O}$ & 296 & 5.27 \\
\hline 6 & 20.49 & 5-Eicosene & $\mathrm{C}_{20} \mathrm{H}_{40}$ & 280 & 9.26 \\
\hline 7 & 21.59 & $9,12,15$-Octadecatrienoic acid, methyl ester & $\mathrm{C}_{19} \mathrm{H}_{32} \mathrm{O}_{2}$ & 292 & 2.23 \\
\hline 8 & 24.08 & 1-Docosene & $\mathrm{C}_{22} \mathrm{H}_{44}$ & 308 & 2.80 \\
\hline 9 & 28.07 & Squalene & $\mathrm{C}_{30} \mathrm{H}_{50}$ & 410 & 12.28 \\
\hline \multicolumn{6}{|c|}{ Methanol extract } \\
\hline 1 & 18.90 & 3,7,11,15-Tetramethyl-2-hexadecen-1-ol & $\mathrm{C}_{20} \mathrm{H}_{40} \mathrm{O}$ & 296 & 16.05 \\
\hline 2 & 19.85 & Heptacosanoic acid, methyl ester & $\mathrm{C}_{28} \mathrm{H}_{56} \mathrm{O}_{2}$ & 424 & 0.57 \\
\hline 3 & 20.24 & n-Hexadecanoic acid & $\mathrm{C}_{16} \mathrm{H}_{32} \mathrm{O}_{2}$ & 256 & 0.95 \\
\hline 4 & 21.60 & $9,12,15$-Octadecatrienoic acid, methyl ester & $\mathrm{C}_{19} \mathrm{H}_{32} \mathrm{O}_{2}$ & 292 & 1.55 \\
\hline 5 & 21.70 & Phytol & $\mathrm{C}_{20} \mathrm{H}_{40} \mathrm{O}$ & 296 & 33.80 \\
\hline 6 & 28.08 & Squalene & $\mathrm{C}_{30} \mathrm{H}_{50}$ & 410 & 17.62 \\
\hline
\end{tabular}

In accordance with the previous findings, most of the identified compounds from this study have also been reported elsewhere in other studies on the same species and other species such as squalene was identified in the hexane, petroleum ether, ethyl acetate and methanol extracts of L. leucocephala leaves was also reported in the whole plants extracts of the same plant from China [8]. Almost all the present phytochemical compounds have been detected in other species such as 9,12,15-Octadecatrienoic acid, methyl ester, phytol, squalene and 9,12Octadecadienoic acid, methyl ester in Cleome chelidonii [10], Pentadecanoic acid, 14-methyl-, methyl ester in indigofera suffruticosa [11] and oxalic acid, allyl hexadecyl ester in Aloe vera [12]. Phytol and squalene were identified as the major compound of methanol extract of L. leucocephala leaves were also reported as the major compound of vernonia amygdalina leaf extracts [13]. Phytol, squalene and nhexadecanoic acid have been detected in the methanol extract of Cassia
Italica leaf [14]. Pentadecanoic acid,14-methyl-,methyl ester and nHexadecanoic acid were present in the ethanolic extract of Indigofera suffruticosa leaves [11]. n-hexadecanoic acid, Phytol, Squalene, and 3,7,11,15-tetramethyl-2-hexadecen-1-ol have been reported in the leaf of ethanol extract of Hugonia mystax [15]. Nine compounds were identified in the leaves of Abrus precatorius and n-hexadecanoic acid was one of these compounds [16]. Squalene, 9,12-octadecadienoic acid (Z,Z), n-hexadecanoic acid, ethyl ester, Phytol and hexadecanoic acid were detected in a leaf of Pleiospermium alatum [17]. The GC-MS analysis has identified 30 compounds from all the solvent extracts from the $L$. leucocephala leaves and some of them have been reported to possess many biological properties such as antimicrobial, anticancer, cancer preventive, diuretic, anti-inflammatory, antioxidant; antitumor, antihistaminic, nematicide, pesticide, antiandrogenic, hypocholesterolemic and hepatoprotective as summarized in table 2.

Table 2: Summary of phytochemical compounds identified from the L. leucocephala leaf extracts and their therapeutic activity

\begin{tabular}{|c|c|c|c|}
\hline No & Compound & Secondary metabolite & Therapeutic activity \\
\hline 1 & Phytol & Diterpene & Antimicrobial, anticancer, cancer preventive, diuretic, anti-inflammatory \\
\hline 2 & Squalene & Triterpene & $\begin{array}{l}\text { Antibacterial, antioxidant, antitumor; cancer-Preventive, chemopreventive; } \\
\text { immunostimulant, lipoxygenase-inhibitor, perfumery, pesticide, sunscreen }\end{array}$ \\
\hline 3 & n-Hexadecanoic acid & Palmitic acid & $\begin{array}{l}\text { Antioxidant, hypocholesterolemic nematicide, pesticide, antiandrogenic, } \\
\text { flavor, hemolytic, 5-alpha reductase inhibitor }\end{array}$ \\
\hline 4 & $\begin{array}{l}\text { Pentadecanoic acid, 14- } \\
\text { methyl-, methyl ester }\end{array}$ & Palmitic acid methyl ester & Antioxidant. \\
\hline 5 & $\begin{array}{l}\text { Hexadecanoic acid, 15- } \\
\text { methyl-, methyl ester }\end{array}$ & Fatty acid ester & Antioxidant, nematicide, pesticide, flavor, antiandrogenic \\
\hline 6 & $\begin{array}{l}\text { 3,7,11,15-Tetramethyl-2- } \\
\text { hexadecen-1-ol }\end{array}$ & Terpene alcohol & Antimicrobial \\
\hline 7 & $\begin{array}{l}\text { 9,12,15-Octadecatrienoic acid, } \\
\text { methyl ester }\end{array}$ & Linolenic acid ester & $\begin{array}{l}\text { Antiinflammatory, insectifuge hypocholesterolemic, cancer preventive, } \\
\text { nematicide, hepatoprotective, insectifuge, antihistaminic, antieczemic, antiacne, } \\
\text { 5-alpha reductase inhibitor, antiandrogenic, antiarthritic, anticoronary }\end{array}$ \\
\hline 8 & $\begin{array}{l}\text { 9,12-Octadecadienoic acid, } \\
\text { methyl ester }\end{array}$ & Linolenic acid ester & $\begin{array}{l}\text { Antiinflammatory, nematicide, insectifuge, hypocholesterolemic, cancer } \\
\text { preventive, hepatoprotective, antihistaminic, antiacne, antiarthritic, antieczemic }\end{array}$ \\
\hline 9 & $\begin{array}{l}\text { Oxalic acid, allyl hexadecyl } \\
\text { ester }\end{array}$ & Dicarboxylic acid & $\begin{array}{l}\text { Acaricide, antiseptic, CNS-paralytic, fatal, hemostatic, irritant, pesticide, } \\
\text { renotoxic, varroacide }\end{array}$ \\
\hline
\end{tabular}

Modified from Dr. Duke's: Phytochemical and Ethnobotanical Databases [18] 
Among the identified phytochemicals, squalene is a triterpene that is an intermediate in the cholesterol biosynthesis pathway [19], and it is used in cosmetics as a natural moisturizer [14, 17]. Squalene is reported to be an antioxidant activity $[17,20,21]$, anticancer activity $[17,22]$ and chemopreventive activity against colon carcinogenesis $[17,23,24]$.

n-Hexadecanoic acid (Palmitic acid) is an intermediate in the biosynthesis of sexual pheromones of some insects $[25,26]$ and it is used as an insecticide and anti-microbial agents [26, 27]. It has the property of antioxidant activity [28] and it is used to decrease the hydrophobicity of virginiamycin in some drugs against Mycobacterium avium [26, 29, 30]. Other antioxidants present were pentadecanoic acid, 14-methyl-, methyl ester and hexadecanoic acid, 15-methyl-, methyl ester.

Phytol is one among the thirty compounds in L. leucocephala leaves which were also found to be effective at different stages of arthritis. It is used as preventive and therapeutic to against arthritis as well as it is a promising novel class of pharmaceuticals for the treatment of rheumatic arthritis and possibly other chronic inflammatory diseases [15, 17, 31]. In addition, it was observed to have antibacterial activities against Staphylococcus aureus by causing damage to cell membranes, as a result, there is a leakage of potassium ions from bacterial cells [14, 32]. It is used along with simple sugar or corn syrup as a hardener in candies and it is a key acyclic diterpene alcohol that is a precursor for vitamins $\mathrm{E}$ and $\mathrm{K}[14]$.

\section{CONCLUSION}

The present phytochemical study of L. leucocephala leaf extracts was studied for the first time using five different solvent extracts with increasing polarities. In fact, this is the first available information about the phytoconstituents of $L$. leucocephala from Malaysia. $L$. leucocephala leaf extracts have revealed the presence of many secondary metabolites. The findings of this study confirmed that the L. leucocephala leaf extracts could be used as antioxidant, anticancer, cancer-preventive, diuretic, antiandrogenic, antimicrobial, antitumor, antiacne, antiarthritic, antieczemic, anti-inflammatory, hypocholesterolemic, insecticide, nematicide and pesticide. The present study, which reveals the presence of components in $L$. leucocephala leaf extracts suggest that the contribution of these compounds on the pharmacological activity should be evaluated.

\section{ACKNOWLEDGMENT}

The authors are thankful to University Malaysia Sarawak for providing necessary facilities to carry out this work.

\section{CONFLICT OF INTERESTS}

\section{Declared none}

\section{REFERENCES}

1. Mohd-Azlan J, Noske RA, Lawes MJ. Resource partitioning by mangrove bird communities in North Australia. Biotropica 2014;46:331-40.

2. Brewbaker JL, Sorensson CT. New tree crops from interspecific Leucaena hybrids. In: Janick J, Simon JE. Eds. Advances in New Crops. Timber Press: Portland; 1990. p. 283-9.

3. Awe FA, Giwa-Ajeniya AO, Akinyemi AA, Ezeri GNO. Phytochemical analysis of Acalypha wilkesiana, Leucaena leucocephala, Pepperomia pellucida and Sena alata leaves. Int J Eng Sci 2013;2:41-4.

4. Brewbaker JL, Plucknett DL, Gonzalez V. Varietal variation and yield trials of Leucaena leucocephala (Koa Haole) in Hawaii. Hawaii Agric Exp qt Res Bull; 1972.

5. Hegarty MP, Schinckel PG, Court RD. Reaction of sheep to the consumption of Leucaena glauca and to its toxic principle mimosine. Aust J Agric Res 1964;15:53-67.

6. Rushkin FR. ed. Leucaena: promising forage and tree crops for the tropics. 2nd ed. National Research Council. Washington, DC: National Academy Press; 1984.

7. Meena Devi VN, Ariharan VN, Nagendra Prasad P. Nutritive value and potential uses of Leucaena Leucocephala as biofuel-a mini review. Res J Pharm Biol Chem Sci 2013;4:515-21.

8. Chen C, Wang Y. Polyprenol from the whole plants of Leucaena leucocephala. J Environ Prot 2010;1:70-2.
9. Salem AZM, Salem MZM, Gonzalez-Ronquillo M, Camacho LM, Cipriano M. Major chemical constituents of Leucaena leucocephala and Salix babylonica leaf extracts. J Trop Agric 2011;49:95-8.

10. Parimalakrishna S, Dey A, Smith A, Manavalan R. Evaluation of anti-inflammatory, antinociceptive and antipyretic effects of methanol extract of Cleome chelidonii. Int J Biol Chem Sci 2007;1:223-8.

11. Elezabeth VD, Arumugam S. GC-MS analysis of bioactive constituents of Indigofera suffruticosa leaves. J Chem Pharm Res 2014;6:294-300.

12. Arunkumar S, Muthuselvam M. Analysis of phytochemical constituents and antimicrobial activities of Aloe vera L. against clinical pathogens. World J Agric Sci 2009;5:572-6.

13. Daniel AO, Folahan O, Ayorinde AG, Adrian A, Ernest BI, Broderick $\mathrm{E}$, et al. Biological activity and mass spectrometric analysis of Vernonia amygdalina fractions. J Biosci Technol 2011;2:287-304.

14. Sermakkani M, Thangapandian V. GC-MS analysis of Cassia italica leaf methanol extract. Asian J Pharm Clin Res 2012;5:90-4.

15. Rajeswari G, Murugan M, Mohan VR. GC-MS analysis of bioactive components of Hugonia mystax L. (Linaceae). Res J Pharm Biol Chem Sci 2012;3:301-8.

16. Gnanavel V, Mart Saral A. GC-MS analysis of petroleum ether and ethanol leaf extracts from Abrus precatorius linn. Int J Pharm Biol Sci 2013;4:37-44.

17. Parthipan B, Suky MGT, Mohan VR. GC-MS analysis of phytocomponents in Pleiospermium alatum (Wall. ex Wight and Arn.) Swingle, (Rutaceae). J Pharm Phytochem 2015;4:216-22.

18. Duke JA. Phytochemical and ethnobotanical databases; 2007. Available from: http: //www.ars-grin.gov/duke/chemactivities.html. [Last accessed on 10 Feb 2016].

19. Huang ZR, Lin YK, Fang JY. Biological and pharmacological activities of squalene and related compounds: potential uses in cosmetic dermatology. Molecules 2009;14:540-54.

20. Lalitharani S, Mohan VR, Regini GS, Kalidass C. GC-MS analysis of ethanolic extract of Pothos scandens leaf. J Herb Med Toxicol 2009;3:159-60.

21. Sutha T, Chidambaram PS, Mohan VR. GC-MS analysis of bioactive components of leaf and stem bark of Kirganelia reticulata Poir (Euphorbiaceae). J Curchem Pharm Sci 2013;3:113-22.

22. Purushoth PT, Panneerselvam P, Suresh R, Clement AW, Balasubramanian S. GC-MS analysis of ethanolic extract of Canthium parviflorum Lamk leaf. J Appl Pharm Sci 2013;2:166-8.

23. Rao CV, Newmark HL, Reddy BS. Chemopreventive effect of squalene on colon cancer. Carcinogen 1998;19:287-97.

24. Alagammal M, Tresina PS, Mohan VR. GC-MS determination of bioactive components of Polygala javana Dc. Int J Curr Pharm Res 2012;4:42-4.

25. Trabalon M, Niogret J, Legrand-Frossi C. Effect of 20hydroxyecdysone on cannibalism, sexual behavior, and contact sex pheromone in the solitary female spider, Tegenaria atrica. General Comparative Endocrinol 2005;144:60-6.

26. Zayed MZ, Fasihuddin BA, Wei-Seng H, Shek-Ling P. GC-MS analysis of phytochemical constituents in leaf extracts of Neolamarckia cadamba (Rubiaceae) from Malaysia. Int J Pharm Pharm Sci 2014;6:123-7.

27. Praveen KP, Kumaravel S, Lalitha C. Screening of antioxidant activity, total phenolics and GC-MS study of Vitex negundo. Afr J Biochem Res 2010;4:191-5.

28. Bharathy V, Uthayakumari F. Bioactive components in leaves of jatropha tanjorensis JL Ellis and Saroja by GC-MS analysis. Int J PharmTech Res 2013;5:1839-43.

29. Rastogi N, Moreau B, Capmau ML, Goh KS, David HL. Antibacterial action of amphiphatic derivatives of isoniazid against the Mycobacterium avium complex. Zentralblatt für Bakteriologie Mikrobiologie und Hygiene 1988;268:456-62.

30. Mingarro I, Lukovic D, Vilar M, Perez-Gil J. Synthetic pulmonary surfactant preparations: new developments and future trends. Curr Med Chem 2008;15:393-403.

31. Ogunlesi M, Okiei W, Ofor E, Osibote AE. Analysis of the essential oil from the dried leaves of Euphorbia hirta Linn 
(Euphorbiaceae), a potential medication for asthma, Afr J Biotech 2009;8:7042-50.

32. Inoue $\mathrm{N}$, Ikawa $\mathrm{M}$, Isotani $\mathrm{A}, \mathrm{Okabe} \mathrm{M}$. The immunoglobulin superfamily protein Izumo is required for sperm to fuse with eggs. Nature 2005;10:234-8.

\section{How to cite this article}

- Mohamed Zaky Zayed, Benedict Samling. Phytochemical constituents of the leaves of Leucaena leucocephala from malaysia. Int J Pharm Pharm Sci 2016;8(12):174-179. 